\title{
The influence of parents' educational practices on young learners' social and academic adaptation
}

\author{
Gina Florentina Tudorache ${ }^{\mathrm{a} *}$, Mihaela Badea ${ }^{\mathrm{a}}$ \\ ${ }^{a}$ Petroleum - Gas University of Ploiești, \#39 Bdv. București, Ploiești, 100680, Romania
}

\begin{abstract}
The study starts from the overwhelming importance that the family has on the child's development, as a result of the multitude of functions not found in other social groups, such as: biological function, procreation function, economic, psychoaffective and educational function. Although all parents' purposeis the harmonious development of children from a cognitive, social and emotional point of view, under the influence of a variety of factors, they manifest educational practices that dose differently care and parental control. Thus, the study considers how parents' action patterns can influence the social and academic adaptation of young school-age students. In this sense, the research sample is made of 18 primary school students whose school period was followed throughout the fundamental acquisition cycle.
\end{abstract}

Keywords: parental practices; warmth; control; autonomy; social adaptation; academic adaptation

\section{Introduction}

The job of a parent, as beautiful as it is, it is very difficult. Sometimes it looks magnificent and satisfying, other times exhausting. A factor that influences the way in which each parent is involved in the care and education of children is determined by the set of beliefs, customs, values, etc. which parents take from the family of origin (Bonchiș, 2011).

Nowadays, it is unanimously accepted that the mission of parenting can only be accomplished effectively if it is based on training in appropriate communication and interaction techniques with children.

Being the first social environment with which the child interacts, the family represents "the basic map on which are marked the paths that the child will follow later in life" (Farcas, 2019, p. 135). Following the trajectory of the child psychological development and evolution, specialized studies (Mitrofan, 2003, Crețu, 2009, Bonchiss, 2011) emphasize the overwhelming importance of the family environment in the development of his personality, as it performs a number of functions, such as biological, procreation, economic, psychoaffective and educational function. In this sense, some researchers strikingly highlight all the responsibilities of this social group: "the family is the primary factor in the child's formation and socialization, representing the fundamental framework within which his psychological and social needs are met as well as the stages of the entire cycle growth and development" (Banciu, Rădulescu, Voicu, 1987, p. 53).

Therefore, family represents the social cell that provides the child with the necessary conditions to follow his evolutionary path. It offers him a small-scale social environment, satisfying his primary needs, giving him attention, affection and security, guidance for a good adaptation to the environment, but also patterns of behavior to which he will relate on his way to maturity.

\footnotetext{
* Corresponding author

E-mail address: ginatudorache16@yahoo.com
} 
Parents' educational practices have a great influence on the evolutionary path of the child. A series of factors, such as cultural norms and values, but also the personal set of beliefs orient the educational practices of adults in two opposite directions: the individualistic one that emphasizes the development of independence, self-confidence and autonomy and the collectivist one that gives importance to obedience, conformity, cooperation and group membership (Mitrofan, 2003).

The principles, methods and procedures according to which the education of the child is carried out determine the set of attitudes, behaviors and educational practices that are configured in a certain educational style. It is based on two dimensions: care and parental control. Care involves increased attention paid to the child, support, affection, stimulation, etc., and parental control refers to the extent to which the child is supervised and disciplined. The way each parent doses the two dimensions determines one of the following parental styles: authoritarian (low care, high control), demanding (high care, high control), permissive (high care, low control), careless (low care, low control) (Harwood, Miller, Vasta, 2010). Each of these has a certain influence on the child, either positive or negative, although the purpose of each parent is to ensure the harmonious development of the child.

The beginning of school is an important event in the child's life that causes significant changes in his personality. During early schooling, the child amplifies his / her relationship skills, acquires knowledge and develops fundamental psychic abilities for the evolutionary stages that will follow. Thus, within the systematized educational approaches, the child acquires fundamental competencies for the intellectual activity, such as: reading, writing, arithmetic calculation and the assimilation of some essential knowledge from several fields of knowledge. Learning to read and write promotes vocabulary development, increased pronunciation and easy and correct expression. (Tomșa, 2005)

Under the influence of curricular and extracurricular activities supported by the family, under the influence of activities in the family environment, but also the way adults guide, direct and support their development, under the influence of interaction with peers are crystallized skills of some schoolchildren, some traits of character, moral consciousness, but also self-awareness and self-image. Also, relationships in the school environment develop sociability, cooperation, sensitivity to the needs of others, reduce egocentrism and develop respect for the other's point of view, a sense of belonging to the group, etc.

At the same time, these social interactions determine adjustments in the moral behavior of the child, who understands the role of the rules for the proper functioning of the group. In the pre-moral stage, described by Kohlberg (2009), at the beginning of early schooling, the child appreciates the deeds according to their repercussions, punishment and reward being fundamental criteria, and the goal he is guided by is to avoid sanctions. As cognitive processes develop, the child tries to model his behavior according to the norms by which the group is guided to enter the grace of others and gain their sympathy (Crețu, apud Kohlberg, 2009).

At the same time, the child becomes interested and influenced by the appreciations of the family, the teacher and his class/groupmates. The new roles and tasks of the child brought by the beginning of school, the results of his school activities, the expectations of the parents and the way they relate to them and, in general, to the whole activity of the child, outline his self-image and self-esteem. Therefore, poor information of the parents on the cognitive processes specific to this stage age and, in general, on the fundamental aspects of the young learner personality development can trigger major difficulties in his evolution. In this sense, the child can outline a distorted image of his own abilities, isolating himself in a certain role, and the interaction with the circumstances of the external environment can have devastating effects on self-esteem and, implicitly, on relationship skills.

In other words, the child's social and academic adaptation are strongly influenced by the way parents dose warmth and control in the process of orientation, guidance and support, but also by the individualistic or collectivist direction they follow in their educational practices. 


\section{Methodology}

\subsection{Objective}

The aim of the present research is to identify the influence that parenting practices have on the social and academic adaptation of young learners. Thus, the following objectives were taken into account: identifying the directions of orientation of the educational practices that the parents manifest in relation to the young learners; identifying the resonance that parents' patterns of action have on the social and academic adaptation of young learners.

In this sense, the research started from the following hypotheses:

H1: The more parents apply educational practices that support children's autonomy, the more they will facilitate their social and academic adaptation;

$\mathrm{H} 2$ : The more parents apply educational practices characterized by an imbalance of dosage between care and control, the more difficult the development of children's autonomy becomes.

\subsection{Participants}

The research sample consisted of 18 second grade students and their parents. The students' school path was closely followed throughout the fundamental acquisition cycle.

\subsection{Instruments and procedure}

The data of the study regarding the educational practices manifested by parents in relation to young learners were collected on the basis of counseling meetings organized every week of the three school years of the fundamental acquisition cycle, but also on the basis of details observed following parental involvement in various school and extracurricular activities All these aspects were constantly noted in observation sheets. Also, in order to have an obvious report illustrating data relevant to the research, a questionnaire-based survey was used. Administered to parents, the questionnaire consisted of 21 closed pre-coded questions, with a varied list of answers so that the respondents could choose as many variants as possible, according to their opinions.

At the same time, the daily teaching activity carried out with these students offered the possibility to analyze the products of the school activities (drawings, compositions, notebooks, etc.), of the school results, of the behavior during the lessons and in the classroom. All these data were gathered on the basis of a careful and systematic follow-up, and the information was constantly recorded in an observation grid. In order to consolidate the data obtained on the basis of observation, free, spontaneous conversation was used, but with well-defined purposes.

\section{Data analysis and results}

Analyzing the data obtained from the implementation of the survey, it was found that the entire group of parents wants to support children to achieve school performance, to develop appropriate attitudes, politeness and relationship skills, to develop self-confidence and courage. But, beyond these common intentions, being influenced by a variety of factors (habits, beliefs, personal values, family circumstances, etc.), they apply different patterns of action, facilitating or complicating the social and academic young learners' adaptation to the school environment.

The educational practices manifested by the surveyed parents are shown in figure below: 


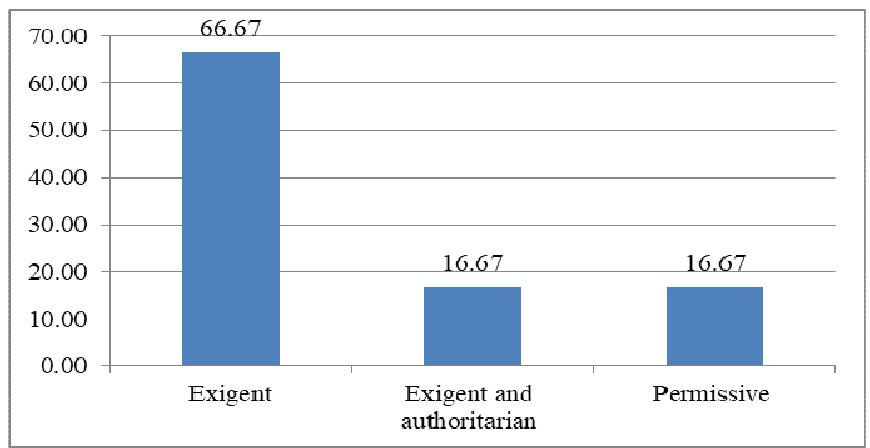

Fig. 1. Parents' educational styles

These data were corroborated, on the one hand, with the aspects collected in the observation grid following the regular meetings with parents, based on the schoolfamily partnership, and, on the other hand, with aspects of social and academic adaptation of young learners.

\section{Results and Discussion}

Among the parents surveyed, 66.66\% (12) mention that they show educational practices corresponding to the demanding educational style, combining high levels of care and control. In this way, they are gentle, caring, have an empathetic, friendly attitude, focus their attention on children and express their affection for them, without being overly tolerant. They show high behavioral control, requesting the observance of the discipline by establishing well-defined rules and are consistent in their observance. On the other hand, they are open to communication, explaining to the children the reasons underlying the rules. At the same time, they encourages children's freedom, maintaining a degree of autonomy appropriate to their age, urging them to research, study, get involved, seek solutions, before giving them guidance, to make decisions in actions that concern them, but to assume their consequences. As Stan and Safta state, "the feeling of autonomy conveys a state of empowerment, the respective individuals feel they are in control, that they are at the root of their actions, that they exist and matter to others, which stimulates the increase in internal motivation " (Stan, Safta, 2020, p. 4)

Because they know how necessary the applications are in consolidating the acquired knowledge, these parents give special importance to the accomplishment of homework. Thus, the time of homework is well established in the children's daily schedule, taking place in the same time slot. At the beginning of the primary cycle, all these learners made their homework benefiting from the assistance of a parent who offered them guidance and supported their effort by valuing their work. After training their children in the ability to take on this responsibility, from the beginning of the second grade, $33.33 \%$ (4) of the parents left them the freedom to express themselves in their homework, keeping, however, the default daily schedule. But, beyond this change, parents continue to check how homework is done, offering children corrective guidance, but also valuing the work done.

Through the feedback they bring to their children, these parents try to develop their intrinsic motivation, emphasizing, through a stimulating language, the competencies they have and which helped them to achieve their goals. They also support their interest, offering them material rewards, materialized in sweets, toys or doing their favorite activities.

Under the influence of these educational practices of parents, young learners feel loved, understood, appreciated, respected and competent, which develops their selfconfidence, high self-esteem and a positive image of themselves, but realistic, in correlation with the skills they have. Thus, both in terms of social relations in the classroom and conduct in teaching activities, students demonstrated initiative, independence, desire for assertion, cooperation, and motivation. Optimistic, sociable 
and self-confident, they have developed good relationships with their classmates, "communication skills being a basic form in the manifestation of social skills" (Bjekić, Zlatić, Bojović, 2020, p. 25). Moreover, they show the desire for selfdevelopment, they act promptly in their attributions, they are always attentive, eager to assert themselves, solve correctly and completely their homework, they constantly work extra hours, they strive to have a neat aspect of the notebooks, they even assume classroom responsibilities related to materials, actions, class activities.

At the same time, they easily managed to acquire the basic competencies specific to the fundamental acquisition cycle (writing, reading, arithmetic calculation), they prove creative attributes, being curious, intuitive, daring, independent in thinking, beyond the guidance offered by the teacher. Balgiu shows in his study that "extremely creative subjects are characterized by high association skills, they are able to bring information, which makes the creative work come out of the unconscious and produce novelty by perfecting existing data and objects" (Balgiu, 2018, p. 85)

Thus, against the background of parental practices that offer children autonomy by fulfilling the need for emotional security, appreciation, freedom of movement, positive discipline, by creating an adequate framework for taking responsibility, but also through the collaborative attitude, they are motivated and eager for selfdevelopment, easily adapting to the school system, both socially and academically. This fact confirms the first working hypothesis: the more parents apply educational practices that support their children's autonomy, the more they will facilitate their social and academic adaptation. Therefore, "the key to success in education is the adoption of simple values such as autonomy, sense of belonging, but also curiosity." (Grigorescu, 2020, p. 18).

At the same time, $16.66 \%$ (3) of the surveyed parents manifest educational practices that alternate action patterns specific to demanding and authoritarian styles. Thus, they combine care and control, which they manifest not only behaviorally, but also psychologically, depending on psychological availability and time.

These parents focus their attention on their children, show care, affection and a friendly attitude, but the degree of tolerance is manifested taking into account vaguely defined rules. Therefore, on the one hand, such parents manifest behavioral control, modeling children's behaviors based on material rewards offered constantly, such as: sweets, toys, favorite activities, etc. Thus, this operative-conditioning technique does nothing but developing children's extrinsic motivation and bring their only temporary agreement with what parents consider desirable. Being accustomed to such reinforcements, outside of this context, children show an attitude contrary to the rules and expectations of their parents. This causes adults to show psychological control, admonishing them, blaming them, and even applying physical punishment.

These patterns of action of parents compromise the development of children's autonomous behavior, and children have "the feeling that they only execute the decisions of another, who is not interested in their ideas and feelings, then that individual perceives themselves as dead weight, which, in turn, significantly decreases our intrinsic motivation" (Stan, Safta, 2020, p. 4). This context invalidates the children's sense of security, generates anxiety, frustration, internal conflicts, suffocates their personal initiatives, sometimes manifesting revolt.

Also, wanting to support their children in achieving good school results, these parents offer them support in completing homework, without maintaining, however, a consistent daily schedule in this regard. In order to complete this task, due to lack of time or psychological availability, parents take the children's roles, thus removing the value of their work.

All these parents' patterns of action have negative implications in adapting children to the requirements of the school system. In this sense, against the background of an emotional insecurity given by the punitive discipline and the psychological control, against the background of the lack of clearly defined rules, of some coercive techniques, but also of the absence of a feedback to support their competences, during the classes, these students show low self-confidence, low self-esteem, inhibition, lack of motivation and initiative. On the other hand, they feel confident when they are offered encouragement and praise to describe their skills, but they do not have enough 
self-confidence that they will be able to do it independently, constantly asking for help from the teacher.

These students have difficulties in acquiring the main competencies specific to the fundamental acquisition cycle (writing, reading, arithmetic calculation), and the absence of action patterns to help their active involvement, supporting their autonomy, makes these tasks difficult. Also, not trusting their own strengths, students do not go far beyond the area of guidance offered by the teacher or in activities that require imagination, creativity, remaining trapped in the role of coercive techniques. At the same time, social skills are still developing, showing close and positive relationships with only some of the classmates, sometimes expressing aggressive behaviors towards others.

Another percentage of $16.66 \%$ (3) of the surveyed parents show educational practices corresponding to the permissive style, combining a high level of care with low control. These parents show a high degree of affection and indulgence, and their expectations are subject to diminished control, encountering difficulties in setting firm limits for their children. Tolerant and inconsistent, they easily give in to children's requests, which allowed them to develop manipulation skills, giving them the feeling that they have control over adults.

These parents listen and encourage their children to express their opinions, to take the initiative in various actions, overlook their inappropriate behaviors, looking for excuses and intervening only when serious consequences occur. In the daily timetable of the students they did not implement a consistent schedule of homework that could have created certain habits appropriate to the requirements of the school system, although they mention that they tried. Based on their domestic role, mothers leave their children available throughout the afternoon to choose a time to do their homework, obtaining a minimum of collaboration from them based on material rewards. Moreover, they offer children step-by-step guidance in completing homework, and even solve certain tasks in their place when the effect of the rewards offered disappears.

In the absence of well-defined rules, but also of a consistent homework schedule, these students have not yet formed the necessary habits to install the appropriate attention and tone for school activities. Being accustomed to postponing their duties, they delay the start of teaching activities and, every time they are asked for something, they wait for the teacher to negotiate, to ask them to do the thing as their parents do, making various comments, such as: It is boring! I will write later! Do I really have to do this? and so on.

These patterns of action of parents bring a low degree of respect and appreciation from children. They generate frustrations, resentments, sometimes causing them to oscillate from being overly good, to being severe, manifesting psychological control, blaming them and adopting abusive verbal behavior, which unbalances children's sense of security.

On the other hand, the high degree of tolerance of the parents and the exaggerated praises outlined to these children a very good opinion about themselves, but exaggerated and unrealistic, which made it difficult for them to adapt in the classroom. At the beginning of the preparatory class, the children were dependent on their mothers, even refusing to join the teaching activities in their absence. These spoiled children had poorly developed social skills, were impatient with others, and showed an egocentric, opposing attitude and maladaptive behaviors.

This dethronement of the central position generated feelings of inferiority for the children, so that throughout the school they had difficult relationships with their classmates. Also, during school activities they show low self-confidence, lack of initiative, low motivation, which brings them mediocre or even poor school results. Also, the development of writing, reading and arithmetic skills is quite difficult, refusing to get involved in activities, their participation in classes being reduced to passive and partial copying of the notions noted on the board; they do not care about the appearance of the notebooks, the personal things, there is always chaos on their bench. 
Therefore, the difficult school life of the $6(33.33 \%)$ students described in the two cases above is triggered by the unbalanced combination of warmth and parental control in various patterns of action, which confirms the second working hypothesis: the more parents apply educational practices characterized by an imbalance of the dosage between care and control, the more difficult the development of the children's autonomy becomes.

\section{Conclusion}

Although the goal of all parents is to ensure their children a harmonious development from a cognitive, social and emotional point of view, under the influence of a variety of factors, they show patterns of action that have different influences on the young learners' evolution.

In order to support children to adapt to the requirements of the school system, but also to gain significant benefits for life, parents' educational practices must be directed towards the development of autonomy, ensuring emotional security, appreciation, freedom of movement, positive discipline, the necessary framework for assuming responsibility, in line with their age. All these are the basis for assuming independence in the process of developing autonomy, and the way in which they are fulfilled determines both the quality of the relations between the parents and the children's school path.

The circumstances in which parents dose in an unbalanced manner care and control, tending towards control-oriented action patterns, compromise children's autonomous development. Children can outline a distorted image of their own abilities, isolating themselves in a certain role, and the interaction with the circumstances of the external environment can have devastating effects on selfesteem, on adaptation to the requirements of the school system, and on relationship skills.

Therefore, the social and academic adaptation of the child is strongly influenced by the way parents dose care and control in the process of orientation, guidance and support, but also by the direction they follow in educational practices (individualist or collectivist).

\section{References}

1. Balgiu, B., A. (2018). The analysis of the creativity styles used by a group of Computer Science students. Journal of Educational Sciences \& Psychology, Vol. VIII (LXX), No. 2/ 2018, 80-87.

2. Banciu, D., Rădulescu S., Voicu, M. (1987). Adolescenții și familia. București: Editura Ştiințifică şi Enciclopedică.

3. Bjekić, D., Zlatić, L., Bojović, M. (2020). Students-teachers' communication competence: basic social communication skills and interaction involvement, Journal of Educational Sciences \& Psychology, Vol. X (LXXII), No. 1/ 2020, 24-34.

4. Bonchiș, E. (2011). Familia și rolul ei în educarea copilului. Iași: Editura Polirom.

5. Crețu, T. (2009). Psihologia vârstelor. Iași: Editura Polirom.

6. Farcaș, G. (2019). Autonomia copilului de vârstă mică. Repere pedagogice. Iași: Editura Polirom.

7. Grigorescu, D. (2020). Curiosity, intrinsic motivation and the pleasure of knowledge in Journal of Educational Sciences \& Psychology, Vol. X (LXXII), No. 1/ 2020, 16-23.

8. Harwood, R., Miller, S., A., Vasta, R. (2010). Psihologia copilului. Iași: Editura Polirom.

9. Mitrofan., I. (coord.). (2003). Cursa cu obstacole a dezvoltării umane. Iași: Editura Polirom.

10. Stan, E., Safta, C. G. (2020). Evaluation and its motivational impact. Case study - future primary school teachers. Journal of Educational Sciences \& Psychology, Vol. X (LXXII) No. $2 / 2020,03-10$.

11. Tomşa, Gh. (coord.). (2005). Psihopedagogie preșcolară şi scolară. București: Editura Revista Învățământului Preșcolar. 